\title{
Automated spectrophotometric heparin assays
}

Citation for published version (APA):

van Putten, J., van de Ruit, M., Beunis, M., \& Hemker, H. C. (1984). Automated spectrophotometric heparin assays: Comparison of methods. Haemostasis, 14(2), 195-204.

https://doi.org/10.1159/000215056

Document status and date:

Published: 01/01/1984

DOI:

10.1159/000215056

Document Version:

Publisher's PDF, also known as Version of record

\section{Please check the document version of this publication:}

- A submitted manuscript is the version of the article upon submission and before peer-review. There can be important differences between the submitted version and the official published version of record.

People interested in the research are advised to contact the author for the final version of the publication, or visit the DOI to the publisher's website.

- The final author version and the galley proof are versions of the publication after peer review.

- The final published version features the final layout of the paper including the volume, issue and page numbers.

Link to publication

\footnotetext{
General rights rights.

- You may freely distribute the URL identifying the publication in the public portal. please follow below link for the End User Agreement:

www.umlib.nl/taverne-license

Take down policy

If you believe that this document breaches copyright please contact us at:

repository@maastrichtuniversity.nl

providing details and we will investigate your claim.
}

Copyright and moral rights for the publications made accessible in the public portal are retained by the authors and/or other copyright owners and it is a condition of accessing publications that users recognise and abide by the legal requirements associated with these

- Users may download and print one copy of any publication from the public portal for the purpose of private study or research.

- You may not further distribute the material or use it for any profit-making activity or commercial gain

If the publication is distributed under the terms of Article $25 \mathrm{fa}$ of the Dutch Copyright Act, indicated by the "Taverne" license above, 


\title{
Automated Spectrophotometric Heparin Assays
}

\section{Comparison of Methods}

\author{
Janjaap van Putten ${ }^{\mathrm{a}}$, Marjo van de Ruit ${ }^{\mathrm{a}}$, Marlène Beunis ${ }^{\mathrm{a}}, \mathrm{H}$. Coenraad Hemker b, 1 \\ a Department of Clinical Chemistry (Head: Dr. J.A.P. Stroes), Stichting Samenwerking Delftse \\ Ziekenhuizen, Delft, The Netherlands; ${ }^{b}$ Rijksuniversiteit Limburg, Maastricht, The Netherlands
}

Key Words. Heparin - Method - Comparison - Anti-IIa activity · Anti-Xa activity . Heparin monitoring

\begin{abstract}
Three automated spectrophotometric heparin assays were investigated. The dayto-day reproducibilities in routine laboratory use were compared with two commercial manual kits for heparin determination. Regression analysis of the activated partial thromboplastin time (APTT) on results of any of the heparin assays shows that the heparin concentration cannot be deduced from the APTT values found in patients receiving heparin. The automated heparin assays that employ thrombin and Chromozym-Th or S-2238 were found to be most suitable for routine heparin determination. Heparin concentrations obtained from assays based on factor $\mathrm{Xa}$ inactivation were not significantly different from those employing thrombin $(p<0.01)$, but revealed a wider standard deviation. The relationship between APTT and heparin level found was not related to the plasma antithrombin III concentration. The extra antithrombin III that is added in the assays had to be freed of heparin neutralising activity to obtain reliable estimates of the heparin concentration in the low range (0-200 U/1).
\end{abstract}

\section{Introduction}

Although the first amidolytic heparin assay was described in 1976 [1], methods based on this principle are not yet in general use. In daily practice, the activated partial thromboplastin time (APTT) is usually employed to determine the dosage of heparin. The APTT

1 We would like to acknowledge the assistance offered by W.T.M. van Bergen Henegouwen. is known to be influenced by many factors besides heparin. We found a remarkable interindividual variation of the APTT in response to standard heparin levels. Spectrophotometric heparin assays are less subject to such interindividual variations [2]. Therefore, we further investigated the reliability of such heparin determinations.

In an earlier paper we described 3 automated spectrophotometric heparin assays (using substrates Chromozym-Th and S2238 with thrombin, and S-2222 with fac- 
tor Xa) [3]. Before releasing these new assays for routine use, day-to-day reproducibility was determined in comparison with 2 available manual heparin kits. Reproducibility was tested with 3 heparinised plasma pools and with 2 commercially available control plasmas.

The purified antithrombin III (AtIII), a reagent used in the spectrophotometric heparin assays in this study, showed a disturbing heparin neutralising effect. This unexpected phenomenon was investigated and compensated for in subsequent assays.

To study the agreement between heparin assays based on thrombin and $\mathrm{Xa}$ inactivation performed on patient plasmas, the heparin levels were determined in plasmas in which APTT was determined routinely. Since the APTT is used to control heparin therapy, the relationships between the APTT and the heparin assays were also determined. To investigate whether variations in plasma AtIII level are associated with the relationships found, we measured the AtIII activity in every plasma.

To determine remaining thrombin activity in either the heparin assay or the AtIII assay, several chromogenic substrates can be used. Two chromogenic substrates (Chromozym-Th and S-2238) are compared here.

\section{Materials and Methods}

Citrated Plasma. By means of a vacuum system with a multi-sample needle, blood was drawn from the antecubital vein. The first tube was not used in this study. Next a second tube (Venoject, black stopper, $4.5 \mathrm{ml}, 3.8 \%$ tri-Na-citrate) was drawn for routine clotting determinations. Within $15 \mathrm{~min}$ the latter sample was centrifuged $\left(10 \mathrm{~min}, 3,500 \mathrm{~g}, 15^{\circ} \mathrm{C}\right)$. The plasma thus obtained contained fewer than $3 \times 10^{9}$ platelets/1.
Pooled Plasma. Equal volumes of citrated plasma from 30 healthy donors were mixed and stored at $-70^{\circ} \mathrm{C}$ in aliquots of $1 \mathrm{ml}$.

AtIII from KabiVitrum, Amsterdam, contained $10 \mathrm{U}$ per vial. One unit was defined as the activity found in $1 \mathrm{ml}$ plasma. The contents of each vial were dissolved in $10 \mathrm{ml}$ distilled water. Where indicated, $100 \mu \mathrm{l}$ heparin $(2,500 \mathrm{U} / \mathrm{l})$ were added to titrate heparin neutralisation.

Thrombin. We used bovine thrombin from Roche, Basel. The contents of each vial (120 USP units) were dissolved in $2.4 \mathrm{ml}$ of distilled water. Before use $1 \mathrm{vol}$ of thrombin was diluted with $5 \mathrm{vol}$ of buffer I.

Factor $\mathrm{Xa}$ used was bovine factor $\mathrm{Xa}$ from Kabi Vitrum, Amsterdam. The contents of each vial (71 nkat) were dissolved in $10 \mathrm{ml}$ of distilled water.

Heparin was obtained from Leo (Emmen, Holland). According to the manufacturer, the solution contained 5,000 USP U/ml of the sodium salt. Dilutions were made with buffered saline $(147 \mathrm{mM} \mathrm{NaCl}$,

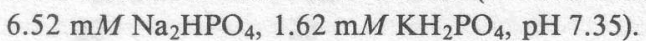

Control plasma for heparin assays: Precichrom I and II (Boehringer-Mannheim, Amsterdam). The contents of each vial were dissolved in $0.5 \mathrm{ml}$ distilled water.

Reproducibility. Heparin was added to a citrate plasma pool, to make 3 pools containing approximately 50, 300 and $800 \mathrm{U} / 1$. These pools were frozen in aliquots of $1 \mathrm{ml} \mathrm{at}-70^{\circ} \mathrm{C}$. On 25 days $1 \mathrm{ml}$ of each pool was thawed at room temperature and assessed in duplicate. Every day a reference curve was made of nonheparinised pooled normal plasma spiked with known amounts of heparin. With each assay the two control plasmas were determined as well.

APTT Reagent. Diagen Kaolin/platelet substitute from Diagnostic Reagents Ltd., Thame, Oxon, England.

Chromogenic substrates used were: Tos-Gly-ProArg-pNA (Chromozym-Th, Boehringer-Mannheim, Amsterdam), Benz-Ile-Glu-Gly-Arg-pNA $\cdot \mathrm{HCl}$ and $\mathrm{H}$-D-Phe-Pip-Arg-pNA - $2 \mathrm{HCl}$ (S-2222 and S-2238 both from KabiVitrum, Amsterdam). Each of the substrates was dissolved in distilled water.

Buffer I (pH 8.4 and I 0.2) contained di-Na-EDTA $(7.5 \mathrm{mM})$, Tris- $\mathrm{HCl}(50 \mathrm{mM})$ and $\mathrm{NaCl}(175 \mathrm{mM})$. Buffer II was as buffer I but with heparin (3 U/l).

Manual chromogenic heparin assays were performed with a photometer with a thermostatically controlled cuvette rack (Beckman No. 25), connected to a recorder (Beckman No. 2000). 
Table I. Analytical conditions of the heparin assays

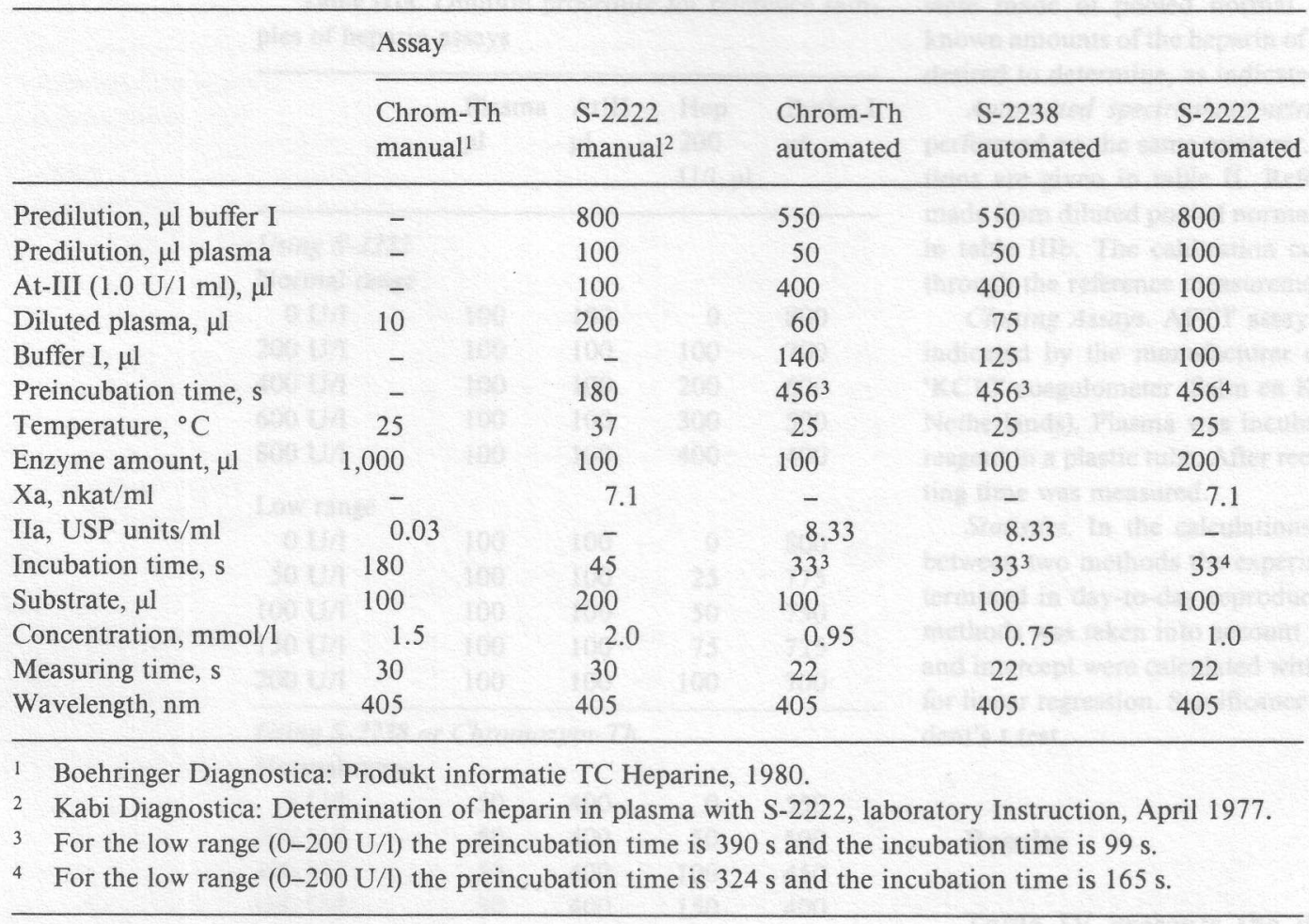

Determinations with the heparin kits TC-heparin 0233714, Boehringer and Coatest/Heparin, KabiVitrum, were performed according to the instruction for kinetic measurements, as supplied by the manufacturers.

Automated Chromogenic Heparin Assays. These were performed on a 'Corona' batch analyzer (Clinicon Amsterdam) as reported before [3]. For testing the reproducibility, the method with reference measurements in the normal range $(0-800 \mathrm{U}$ of heparin/l plasma) were used. Heparin neutralising capacity in the AtIII reagent was tested with a method adapted for measuring low heparin $(0-200)$ concentrations by an increase of the incubation time. This causes the reference curve to steepen, thus increasing the sensitivity of the assay. The higher heparin concentrations (250800 ) cannot be determined reliably, because the enzyme concentration becomes rate limiting on prolonged incubation. The conditions of the heparin assays are summarised in table I. Reference samples
Table II. Analytical conditions for the automated AtIII assays

Chromogenic substrate

Chromozym-Th/S-2238

Predilution, $\mu$ l buffer I $\quad 900$

Predilution, $\mu$ l plasma $\quad 100$

Diluted plasma, $\mu \mathrm{l} \quad 15$

Buffer II, $\mu \mathrm{l} \quad 400$

Preincubation time, $s \quad 126$

Temperature, ${ }^{\circ} \mathrm{C} \quad 25$

Enzyme amount, $\mu \mathrm{l} \quad 100$

IIa, USP units $/ \mathrm{ml} \quad 8.33$

Incubation time, $s \quad 330$

Substrate, $\mu \mathrm{l} \quad 100$

Concentration (mmol/l), $\mu \mathrm{l} \quad 0.95 / 0.75$

Measuring time, $\mathrm{s} \quad 22$

Wavelength, $\mathrm{nm} \quad 405$ 
Table IIIa. Dilution procedure for reference samples of heparin assays

\begin{tabular}{lllll}
\hline Plasma & AtIII & Hep & Buffer I \\
$\mu \mathrm{l}$ & $\mu \mathrm{l}$ & 200 & $\mu \mathrm{l}$ \\
& & $\mathrm{U} / 1, \mu \mathrm{l}$ &
\end{tabular}

\begin{tabular}{lllrl}
\hline $\begin{array}{l}\text { Using S-2222 } \\
\text { Normal range } \\
\text { 0 U/1 }\end{array}$ & 100 & 100 & 0 & 800 \\
$200 \mathrm{U} / 1$ & 100 & 100 & 100 & 700 \\
$400 \mathrm{U} / 1$ & 100 & 100 & 200 & 600 \\
$600 \mathrm{U} / 1$ & 100 & 100 & 300 & 500 \\
$800 \mathrm{U} / 1$ & 100 & 100 & 400 & 400 \\
Low range & & & & \\
$0 \mathrm{U} / 1$ & 100 & 100 & 0 & 800 \\
$50 \mathrm{U} / 1$ & 100 & 100 & 25 & 775 \\
$100 \mathrm{U} / 1$ & 100 & 100 & 50 & 750 \\
$150 \mathrm{U} / 1$ & 100 & 100 & 75 & 725 \\
$200 \mathrm{U} / 1$ & 100 & 100 & 100 & 700 \\
\hline
\end{tabular}

Using S-2238 or Chromozym-Th

Normal range

\begin{tabular}{crrrr}
$0 \mathrm{U} / 1$ & 50 & 400 & 0 & 550 \\
$200 \mathrm{U} / 1$ & 50 & 400 & 50 & 500 \\
$400 \mathrm{U} / 1$ & 50 & 400 & 100 & 450 \\
$600 \mathrm{U} / 1$ & 50 & 400 & 150 & 400 \\
$800 \mathrm{U} / 1$ & 50 & 400 & 200 & 350 \\
Low range & & & & \\
$0 \mathrm{U} / 1$ & 50 & 400 & $0^{1}$ & 550 \\
$50 \mathrm{U} / 1$ & 50 & 400 & $25^{1}$ & 525 \\
$100 \mathrm{U} / 1$ & 50 & 400 & $50^{1}$ & 500 \\
$150 \mathrm{U} / 1$ & 50 & 400 & $75^{1}$ & 475 \\
$200 \mathrm{U} / 1$ & 50 & 400 & $100^{1}$ & 450 \\
\hline
\end{tabular}

1 Hep $100 \mathrm{U} / 1$.

Table IIIb. Dilution procedure for reference samples of AtIII assays with S-2238 or Chromozym-Th

\begin{tabular}{rcc}
\hline$\%$ AtIII & Plasma, $\mu \mathrm{l}$ & Buffer II, $\mu \mathrm{l}$ \\
\hline 0 & 0 & 1,000 \\
50 & 50 & 950 \\
70 & 70 & 930 \\
100 & 100 & 900 \\
125 & 100 & 700 \\
\hline
\end{tabular}

were made of pooled normal plasma spiked with known amounts of the heparin of the same batch as we desired to determine, as indicated in table IIIa.

Automated spectrophotometric AtIII assays were performed on the same analyzer. The reaction conditions are given in table II. Reference samples were made from diluted pooled normal plasma as indicated in table IIIb. The calibration curve was a linear fit through the reference measurements.

Clotting Assays. APTT assays were performed as indicated by the manufacturer of the reagent, on a ' $\mathrm{KC10}$ ' coagulometer (Salm en Kipp, Breukelen, The Netherlands). Plasma was incubated with the APTT reagent in a plastic tube. After recalcification, the clotting time was measured.

Statistics. In the calculations of the relationship between two methods the experimental variance (determined in day-to-day reproducibility tests) of both methods was taken into account [4]. The SD of slope and intercept were calculated with the simple formula for linear regression. Significance was tested with Student's $t$ test.

\section{Results}

Table IV presents the day-to-day reproducibility of the assays. At heparin levels in the therapeutic range (300-800 U/1), the SD is more or less proportional to the level found. At lower heparin levels the SD seems to be absolute, which tends to make estimates of the heparin level below $100 \mathrm{U} / 1$ relatively inaccurate. Those results were obtained with the reference curves ranging from 0 to $800 \mathrm{U} / 1$. The number of days (n) listed indicate the practical use of the assay. Originally, $\mathrm{n}$ was 24 for each assay. Reference measurements, that would not allow a fair fit of a curve through them, resulted in unsafe data for clinicians. Such data were discarded and the (n) in table IV was decreased by 1.

An example of a calculated reference curve of the heparin assay based on thrombin inactivation is the dashed line in figure 1. This line was fitted through measurements 
Table IV. Day-to-day reproducibility of the assays

\begin{tabular}{|c|c|c|c|c|c|}
\hline & $\begin{array}{l}\text { Pool } \\
1\end{array}$ & $\begin{array}{l}\text { Pool } \\
2\end{array}$ & $\begin{array}{l}\text { Pool } \\
3\end{array}$ & $\begin{array}{l}\mathrm{CP} \\
\mathrm{I}\end{array}$ & $\begin{array}{l}\text { CP } \\
\text { II }\end{array}$ \\
\hline $\begin{array}{l}\text { Approximate heparin } \\
\text { concentration, } U / 1\end{array}$ & 50 & 300 & 800 & 270 & 750 \\
\hline \multicolumn{6}{|l|}{$\begin{array}{l}\text { Assay } \\
\text { Manual kits }\end{array}$} \\
\hline Chrom Th, U/1 & $\begin{array}{c}57 \\
18 \\
(16)\end{array}$ & $\begin{array}{r}288 \\
57 \\
(17)\end{array}$ & $\begin{array}{l}628 \\
127 \\
(12)\end{array}$ & $\begin{array}{c}215 \\
78 \\
(18)\end{array}$ & $\begin{array}{r}1,543 \\
133 \\
(13)\end{array}$ \\
\hline $\mathrm{S}-2222, \mathrm{U} / 1$ & $\begin{array}{c}39 \\
19 \\
(21)\end{array}$ & $\begin{array}{c}315 \\
40 \\
(22)\end{array}$ & $\begin{array}{c}803 \\
92 \\
(15)\end{array}$ & $\begin{array}{c}299 \\
40 \\
(22)\end{array}$ & $\begin{array}{r}1,322 \\
370 \\
(4)\end{array}$ \\
\hline $\begin{array}{l}\text { Automated assays } \\
\text { Chrom Th, U/1 }\end{array}$ & $\begin{array}{c}89 \\
17 \\
(22)\end{array}$ & $\begin{array}{r}290 \\
17 \\
(23)\end{array}$ & $\begin{array}{c}765 \\
53 \\
(23)\end{array}$ & $\begin{array}{c}175 \\
20 \\
(23)\end{array}$ & $\begin{array}{r}1,390 \\
238 \\
(17)\end{array}$ \\
\hline $\mathrm{S}-2238, \mathrm{U} / 1$ & $\begin{array}{c}54 \\
29 \\
(24)\end{array}$ & $\begin{array}{c}244 \\
28 \\
(23)\end{array}$ & $\begin{array}{c}758 \\
55 \\
(23)\end{array}$ & $\begin{array}{c}218 \\
33 \\
(23)\end{array}$ & $\begin{array}{r}1,353 \\
313 \\
(12)\end{array}$ \\
\hline $\mathrm{S}-2222, \mathrm{U} / 1$ & $\begin{array}{c}-3 \\
67 \\
(23)\end{array}$ & $\begin{array}{c}206 \\
56 \\
(22)\end{array}$ & $\begin{array}{c}796 \\
86 \\
(23)\end{array}$ & $\begin{array}{c}105 \\
57 \\
(24)\end{array}$ & $\begin{array}{r}1,377 \\
219 \\
(4)\end{array}$ \\
\hline
\end{tabular}

For each assay the mean, the standard deviation and the number (in parentheses) of data points are given. $\mathrm{CP}=$ Control plasma.

obtained at intervals of $200 \mathrm{U} / 1$ of heparin. Extra measurements at $50-\mathrm{U} / 1$ intervals in the low range $(\Delta)$ clearly show the dashed reference line not to be applicable there $(0-200$ $\mathrm{U} / \mathrm{l})$. It appeared that the extent of the deviations of the reference curves shown at the low heparin concentrations was strongly dependent upon the amount of AtIII added, both in the anti-IIa and in the anti-Xa test (results not shown). This phenomenon can be avoided by adding $100 \mu \mathrm{l}$ of heparin $(2,500 \mathrm{U} / 1)$ to each vial of $10 \mathrm{ml}$ AtIII solution $(1 \mathrm{U} / \mathrm{ml})$, as is shown by the linear refer- ence curve $(\bullet$, solid line) in figure 1 . Identical observations were made with factor $\mathrm{Xa}$ inactivation (not shown).

Comparison of the assay that uses thrombin (with S-2238) with the assay that employs $\mathrm{Xa}$ (with S-2222) were performed on determinations in the range of $0-800 \mathrm{U} / 1$. We found an acceptable agreement between the two methods (fig. 2). The relationship Y (S2222) $=a+b X(S-2238)$ showed an intercept of $13 \pm 10 \mathrm{U} / 1$ and a slope of $0.97 \pm 0.02$. Regression analysis was also done for subpopulations selected by AtIII level (0-60\%, 


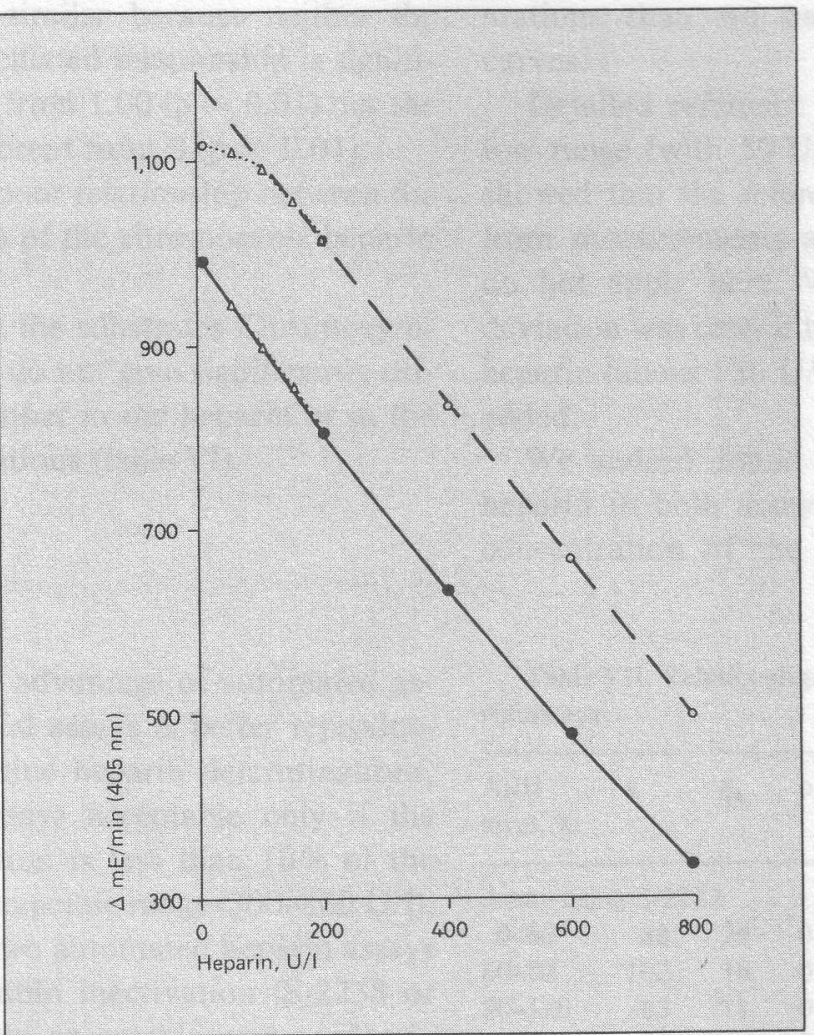

Fig. 1. Reference curves (200 U/1 interval measurements) of the heparin assay using S-2238 (with thrombin) with (solid line) and without (dashed line) heparin added to the AtIII reagent. Connected by a dotted line, intermediate measurements $(50 \mathrm{U} / 1$ intervals) in the low range are depicted $(\Delta)$.

Table V. Relationship between anti-Xa and antiIIa assays

\begin{tabular}{lrrlrrr}
\hline $\begin{array}{l}\text { AtIII } \\
\text { level, \% }\end{array}$ & a, U/l & $\mathrm{S}_{\mathrm{a}}, \mathrm{U} / \mathrm{l}$ & $\mathrm{b}$ & $\mathrm{S}_{\mathrm{b}}$ & $\mathrm{n}$ & $\mathrm{r}$ \\
\hline $0-60$ & 20 & - & 0.92 & - & 2 & 1.00 \\
$60-80$ & 0 & 9 & 1.00 & 0.02 & 45 & 0.98 \\
$80-120$ & 31 & 22 & 0.93 & 0.05 & 32 & 0.94 \\
$0-200$ & 13 & 10 & 0.97 & 0.02 & 77 & 0.96
\end{tabular}

Relationships between test results of heparin assays based on thrombin inactivation and measured with S-2238 ( $\mathrm{x}$ in the equation: $\mathrm{y}=\mathrm{a}+\mathrm{b} \cdot \mathrm{x}$ ) and based on Xa inactivation (y), split up by level of AtIII. The standard deviation of intercepts $\left(\mathrm{S}_{\mathrm{a}}\right)$ as well as of the slopes $\left(\mathrm{S}_{\mathrm{b}}\right)$ are given. The results of both assays are significantly not different $(\mathrm{p}>0.01)$. The last column shows the correlation coefficient $(r)$.
Table VI. Comparison between Chromozym-Th and $\mathrm{S}-2238$

\begin{tabular}{llllllll}
\hline Assay & a & $\mathrm{S}_{\mathrm{a}}$ & $\mathrm{b}$ & $\mathrm{S}_{\mathrm{b}}$ & $\mathrm{n}$ & $\mathrm{r}$ \\
\hline $\begin{array}{l}\text { Heparin } \\
\text { assay }\end{array}$ & $14 \mathrm{U} / 1$ & $9 \mathrm{U} / 1$ & 0.99 & 0.02 & 67 & 0.97 \\
\hline $\begin{array}{l}\text { AtIII } \\
\text { assay }\end{array}$ & $3 \%$ & $4 \%$ & 1.00 & 0.05 & 71 & 0.87 \\
\hline
\end{tabular}

Relationships $(y=a+b \cdot x)$ between results of assays using S-2238 (x) and results of assays using Chromozym-Th (y). The standard deviations of intercepts $\left(\mathrm{S}_{\mathrm{a}}\right)$ as well as of the slopes $\left(\mathrm{S}_{\mathrm{b}}\right)$ are given. The results of both assays are significantly $(p>0.01)$ not different. The last column shows the correlation coefficient ( $\mathrm{r}$ ).

For AtIII $100 \%$ is the activity found in $1 \mathrm{ml}$ of pooled normal plasma and defined as $1 \mathrm{U}$. 
60-80\% and $80-120 \%$ AtIII). This did not reveal an influence of AtIII on this relationship (table V). The results of both assays may be considered similar because neither the slope of the calculated relationship is significantly different from $1.00(p>0.01)$ nor the intercept is different from $0(p>0.01)$.

We found a poor relationship between the APTT and each of the chromogenic heparin assays (fig. 3).

Assays using the substrates ChromozymTh and S-2238 do not give significantly different results, either in the heparin or in the AtIII determinations (table VI).

\section{Discussion}

An expected advantage of automated assays over manual assays is better reproducibility. For routine heparin determinations, we consider assays acceptable only if the standard deviation is less than $10 \%$ of the result in the therapeutic range (300-800 U/1). The SD of the two automated heparin assays based on thrombin inactivation (S-2238 or Chrom-Th) were acceptable and evidently lower than the SD of the assay based on factor Xa inactivation.

In routine practice we need for all tests some control material in order to determine the quality of the used reagents and instruments. For quality control of the automated as well as of the manual spectrophotometric heparin assays the heparinised plasma pools were as good as the tested control plasmas Precichrom I and II, since the SD of the latter two was as high as that of the pools. However, we prefer the heparinised plasma pools because the value of Precichrom II was often out of range, as can be deduced from the low number of observations ( $\mathrm{n}$ ) in the last col- umn in table IV. This can very well be due to the fact that the commercially available control plasmas may contain other heparin preparations than we used for the reference curves.

Detailed reference measurements in the low range (with $50 \mathrm{U} / 1$ plasma increments) showed that the reference curves calculated from measurements at high concentrations do not apply here. We presume that this deviation was caused by the neutralisation of heparin (about $150 \mathrm{U} / 1$ plasma) by the AtIII added.

We indeed found the neutralisation of heparin in both assays to be related to the concentration of the added AtIII reagent.

Table VII. Relationship between APTT and heparin assays

\begin{tabular}{lllllllll}
\hline $\begin{array}{l}\text { AtIII } \\
\text { level, } \%\end{array}$ & a & $\mathrm{S}_{\mathrm{a}}$ & $\mathrm{b}$ & $\mathrm{S}_{\mathrm{b}}$ & $\mathrm{n}$ & $\mathrm{r}$ \\
\hline
\end{tabular}

\begin{tabular}{ccccccc}
\hline \multicolumn{7}{c}{ Assay using S-2222 } \\
$0-60$ & 88 & 25 & 0.27 & 0.07 & 7 & 0.83 \\
$60-80$ & 102 & 16 & 0.25 & 0.05 & 37 & 0.49 \\
$80-120$ & 63 & 11 & 0.19 & 0.03 & 28 & 0.69 \\
$0-200$ & 83 & 11 & 0.24 & 0.03 & 68 & 0.57 \\
\hline Assay using S-2238 & 73 & 39 & 0.30 & 0.12 & 7 & 0.72 \\
$0-60$ & 73 & & & \\
$60-80$ & 100 & 17 & 0.24 & 0.05 & 40 & 0.53 \\
$80-120$ & 60 & 12 & 0.22 & 0.03 & 29 & 0.71 \\
$0-200$ & 76 & 11 & 0.27 & 0.03 & 71 & 0.60 \\
\hline Assay using Chromozym-Th & & & \\
$0-60$ & 66 & 38 & 0.33 & 0.12 & 7 & 0.75 \\
$60-80$ & 106 & 20 & 0.21 & 0.06 & 38 & 0.47 \\
$80-120$ & 62 & 14 & 0.20 & 0.04 & 27 & 0.66 \\
$0-200$ & 80 & 13 & 0.24 & 0.04 & 67 & 0.55 \\
\hline
\end{tabular}

Relationships between APTT ( $x$ in the equation: $y=a+b \cdot x)$ and results of heparin assays (y), split up by level of AtIII. The SD of the intercept $\left(\mathrm{S}_{\mathrm{a}}\right)$ as well as of the slope $\left(\mathrm{S}_{\mathrm{b}}\right)$ are given. The last column shows the correlation coefficient $(r)$. 


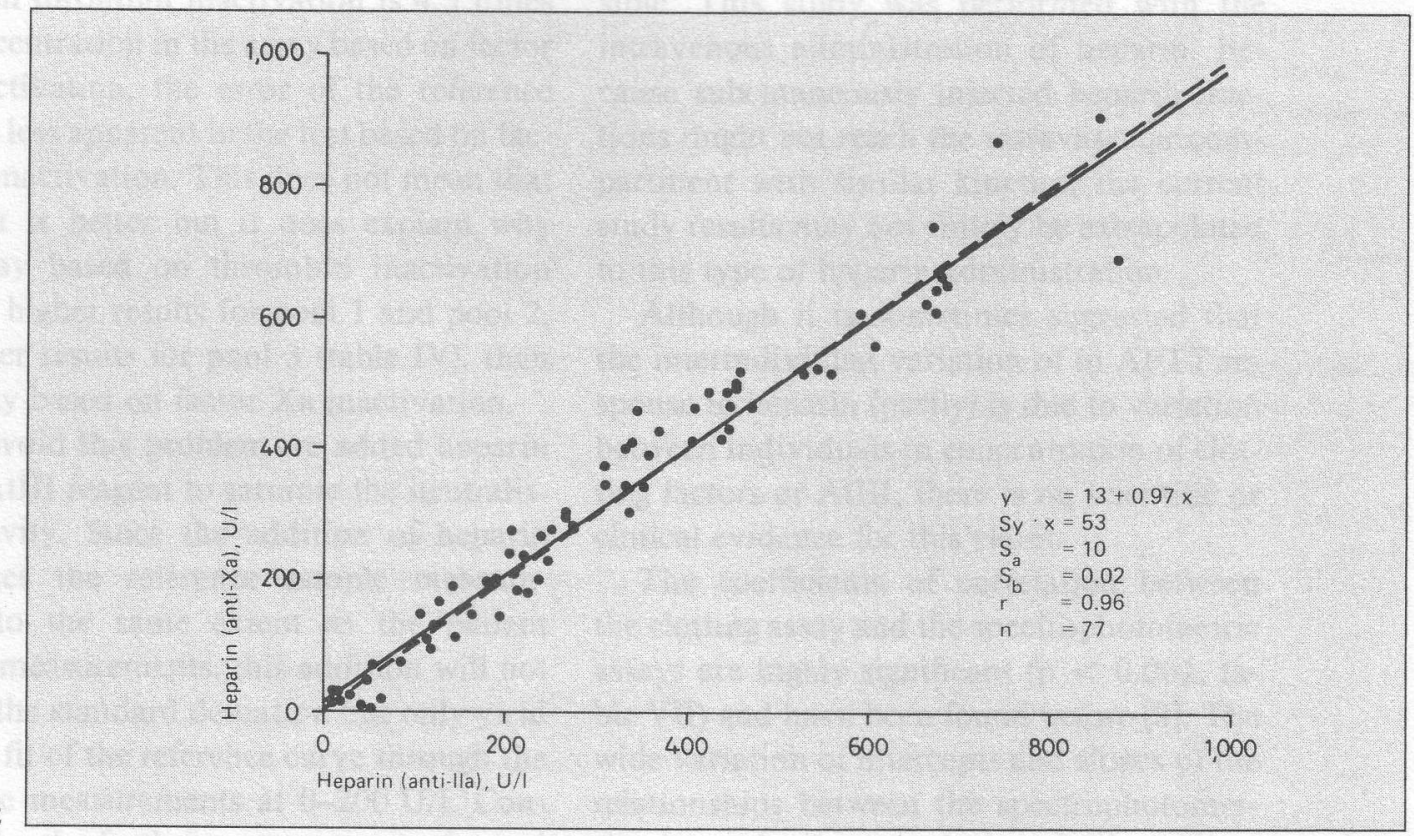

2

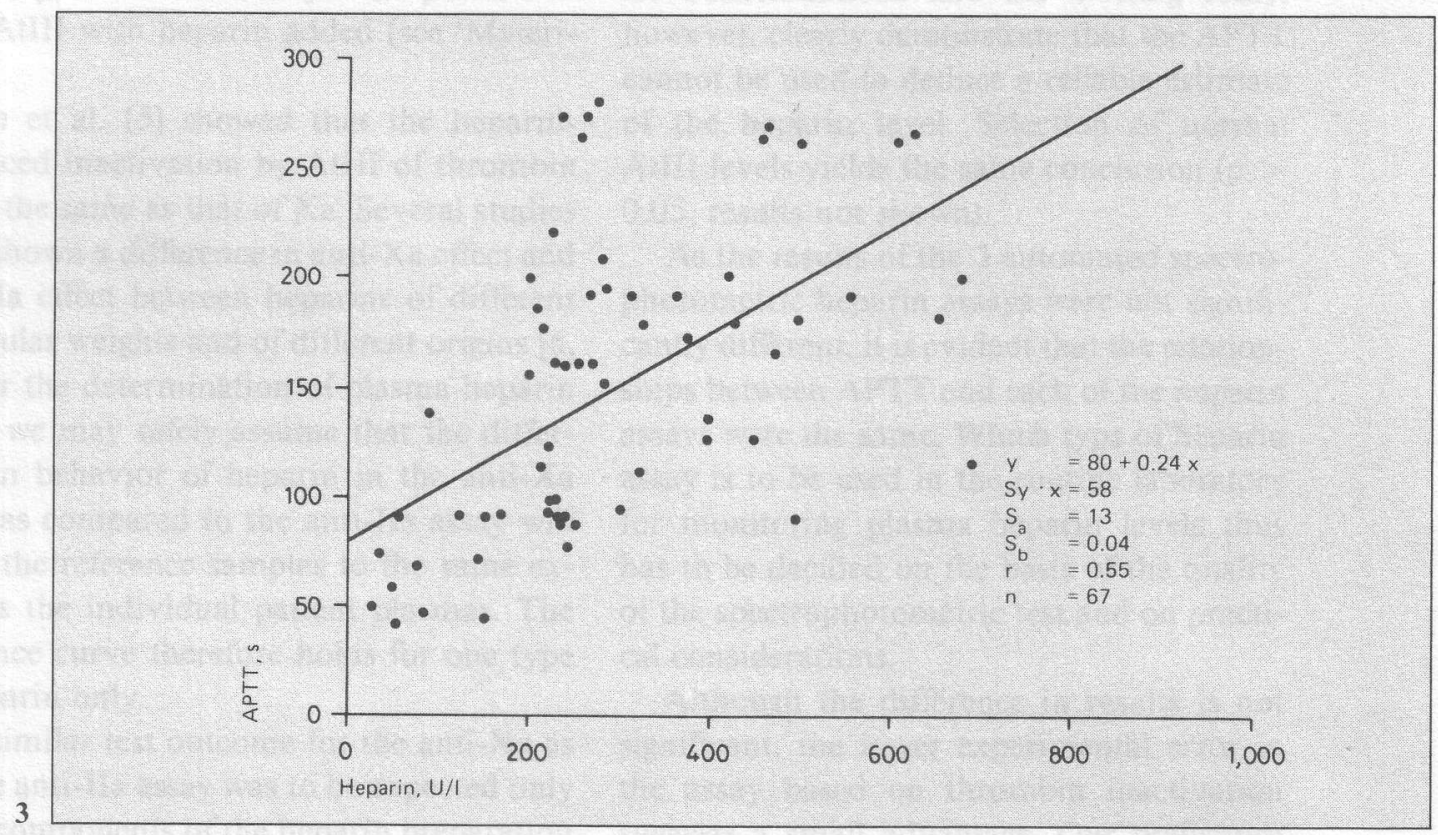

Fig. 2. Relationships between a heparin assay based on thrombin inactivation with $\mathrm{S}-2238$ (x axis) and the heparin assay based on factor $\mathrm{Xa}$ inactivation with S-2222 (y axis). See also table V.
Fig. 3. Relationships between spectrophotometric determined heparin levels ( $\mathrm{x}$ axis) and the APTT (y axis); heparin assay with Chromozym-Th based on thrombin inactivation. See also table VII. 
Since the AtIII concentration in the assay based on thrombin inactivation is 4.5 times the concentration in the assay based on factor $\mathrm{Xa}$ inactivation, the error of the reference curve is less apparent in the test based on factor $\mathrm{Xa}$ inactivation. This does not mean that this test is better but it does explain why the assay based on thrombin inactivation showed higher results for pool 1 and pool 2, but lower results for pool 3 (table IV), than the assay based on factor Xa inactivation.

To avoid this problem we added heparin to the AtIII reagent to saturate the neutralising activity. Since the addition of heparin influences the reference sample measurements to the same extent as the patient plasma measurements, this addition will not change the standard deviation but only yield a better fit of the reference curve through the reference measurements at 0-200 U/1. Consequently, the further assays were performed with AtIII with heparin added (see 'Materials').

Yin et al. [5] showed that the heparinenhanced inactivation by AtIII of thrombin is not the same as that of Xa. Several studies have shown a difference in anti-Xa effect and anti-IIa effect between heparins of different molecular weights and of different origins $[6$, 7]. For the determination of plasma heparin levels we may safely assume that the difference in behavior of heparin in the anti-Xa assay as compared to the anti-IIa assay will affect the reference samples to the same extent as the individual patient plasmas. The reference curve therefore holds for one type of heparin only.

A similar test outcome for the anti-Xa as for the anti-IIa assay was to be expected only if the components of the heparin preparation injected retained the same relative concentrations in the patient plasma. The results shown in figure 2 and table $\mathrm{V}$ make this plausible. This study was performed with the intravenous administration of heparin. Because subcutaneously injected heparin fractions might not reach the intravascular compartment with similar kinetics, the current study results may not simply be extrapolated to this type of heparin administration.

Although it is sometimes suggested that the interindividual variation of in APTT response to heparin (partly) is due to variation between individuals in concentration of clotting factors or AtIII, there is no scientific or clinical evidence for this claim.

The coefficients of correlation between the clotting assay and the spectrophotometric assays are highly significant $(\mathrm{p}<0.001$, table VII) and have been found before [8]. The wide variation of intercepts and slopes of the relationships between the spectrophotometric determinations and the clotting assay, however, clearly demonstrate that the APTT cannot be used to deduce a reliable estimate of the heparin level. Selection of normal AtIII levels yields the same conclusion ( $p>$ 0.05 , results not shown).

As the results of the 3 automated spectrophotometric heparin assays were not significantly different, it is evident that the relationships between APTT and each of the heparin assays were the same. Which type of heparin assay is to be used in the routine laboratory for monitoring plasma heparin levels thus has to be decided on the basis of the quality of the spectrophotometric test and on practical considerations.

Although the difference in results is not significant, the lower experimental error in the assay based on thrombin inactivation suggests a small advantage. Our preference for this assay over the assay based on factor $\mathrm{Xa}$ inactivation is also based on the fact that 
the same reagents can be used for the heparin determination as for the AtIII determination. Moreover, in previous experiments we showed that high heparin concentrations can be measured with the anti-IIa method after extreme dilution with buffer. No grounds could be found to prefer either S-2238 or Chromozym-Th.

\section{References}

1 Teien, A.N.; Lee, M.; Abildgaard, U.: Assay of heparin using a chromogenic substrate for activated factor X. Thromb. Res. 8: 413-416 (1976).

2 Putten, J.J. van; Ruit, M. van de; Beunis, M.; Hemker, H.C.: Interindividual variation in relationships between plasma heparin concentration and the results of five heparin assays. Clinica chim. Acta 122: 261-270 (1982).

3 Putten, J.J. van; Ruit, M. van de; Beunis, M.; Hemker, H.C.: Automated determination of heparin with chromogenic substrates. Haemostasis 14 : 184-194 (1984).

4 Davies, O.; Goldsmith, P.L.: Statistical methods in research and production; 4th ed. (Langman Group Lim, London 1976).

5 Yin, E.T.; Wessler, S.; Stoll, P.J.: Biological properties for the naturally occurring plasma inhibitor to activated factor X. J. biol. Chem. 246: 37033711 (1971).
6 Bianchini, P.; Osima, B.; Parma, B.; Nader, H.B.; Dietrich, C.P.: Pharmacological activities of heparins obtained from different tissues: enrichment of heparin fractions with high lipoprotein lipase, antihemolytic and anticoagulant activities by molecular sieving and antithrombin III affinity chromatography. J. Pharmac. exp. Ther. 220: 406-410 (1982).

7 Kakkar, V.V.; Djazaeri, B.; Fok, J.; Fletcher, M.; Scully, M.F.; Westwick, J.: Low-molecular-weight heparin and prevention of postoperative deep vein thrombosis. Br. med. J. 284: 375-379 (1982).

8 Bounameaux, H.; Marbet, G.A.; Laemmle, B.; Eichlisberger, R.; Duckert, F.: Monitoring of heparin treatment. Am. J. clin. Path. 74: 68-73 (1980).

Received: September 3, 1982

Accepted in revised form by editor

J.C.W. van de Loo: October 25, 1983

M.H. Beunis,

Department of Clinical Chemistry, SSDZ,

PO Box 5010,

NL-2600 GA Delft (The Netherlands) 